\section{Inhibition of dopamine biosynthesis by gonadotropin-releasing hormone in rat}

\author{
W-K. Wang, L. S. Jenq, Y. Chiang \& N. K. Chien \\ Biophysics Laboratory, Institute of Physics, Academia Sinica, \\ Taipei, Taiwan 115
}

There is evidence that the neuroendocrine system can be modulated by endogenous opioid peptides (for a review see ref. 1). Recently Rotsztejn et $a .^{2}$ have ruled out a direct effect of Met-enkephalin on release of gonadotropin-releasing hormone (GnRH). Instead they postulated that Met-enkephalin inhibits the secretion of dopamine from dopaminergic neurones thereby reducing the dopamine-stimulated release of $\mathrm{GnRH}$ from the hypothalamus. We report here evidence that $\mathrm{GnRH}$ can itself supress dopamine synthesis in the rat. The fact that the dopamine neurone and GnRH-secreting cell are adjacent to each other ${ }^{3}$ suggests a feedback mechanism of regulating $\mathrm{GnRH}$ release.

Sprague-Dawley rats $(180-230 \mathrm{~g})$ were killed by decapitation. The corpus striatum was dissected on ice and homogenized in 10 vols $0.32 \mathrm{M}$ sucrose using a Teflon pestle tissue homogenizer. After centrifugation at $1,000 \mathrm{~g}$ for $15 \mathrm{~min}, 50 \mu \mathrm{l}$ aliquots of the synaptosome-containing supernatant were incubated with $150 \mu \mathrm{l}$ of physiological medium containing $(\mathrm{mM})$ : $125 \mathrm{NaCl} ; 1.48 \mathrm{CaCl}_{2} ; 4.8 \mathrm{KCl} ; 2.5 \mathrm{MgSO}_{4} ; 22 \mathrm{NaH}_{2} \mathrm{PO}_{4} ; 10$ $\mathrm{NaHCO}_{3} ; 16$ glucose, to give a final $p \mathrm{H}$ of 6.6 after equilibration with $95 \% \mathrm{O}_{2}-5 \% \mathrm{CO}_{2}$ at $37^{\circ} \mathrm{C}$. $\left[1-{ }^{14} \mathrm{C}\right]$ tyrosine (specific activity $\left.50 \mathrm{mCi} \mathrm{mmol}^{-1}\right)$ at a concentration of $10 \mu \mathrm{M}$ was added to the preparation, together with bacitracin $\left(10^{-5} \mathrm{M}\right)$ to reduce the degradation of polypeptides. $\mathrm{GnRH}$, Met-enkephalin or naloxone were added to the incubation medium with $10 \mu \mathrm{l}$ $0.1 \mathrm{M}$ phosphorous buffer $p \mathrm{H} 6.6$ as carrier; controls recieved the buffer alone. The method used to determine dopamine synthesis was modified from that of Weiner ${ }^{4}$ and Kuzcenski ${ }^{5}$, who measured the release of ${ }^{14} \mathrm{CO}_{2}$ from $\left[1-{ }^{14} \mathrm{C}\right]$ tyrosine. We simplified the incubation medium to mimic the cerebrospinal fluid and used a respirometer to supply oxygen and allow continuous measurement of the ${ }^{14} \mathrm{CO}_{2}$ output from the tissue ${ }^{6}$. Addition of iodotyrosine $\left(5 \times 10^{-4} \mathrm{M}\right)$ to the incubation medium inhibits $>90 \%$ of the ${ }^{14} \mathrm{CO}_{2}$ release ${ }^{7}$.

Dopamine formation was calculated when the ${ }^{14} \mathrm{CO}_{2}$ output had reached a steady state, that is, after $50 \mathrm{~min}$ incubation. The rate of dopamine synthesis in 10 preparations was $0.2 \pm$ $0.02 \mathrm{~mol} \mathrm{mg}^{-1} \mathrm{~min}^{-1}$ (mean \pm s.d.).

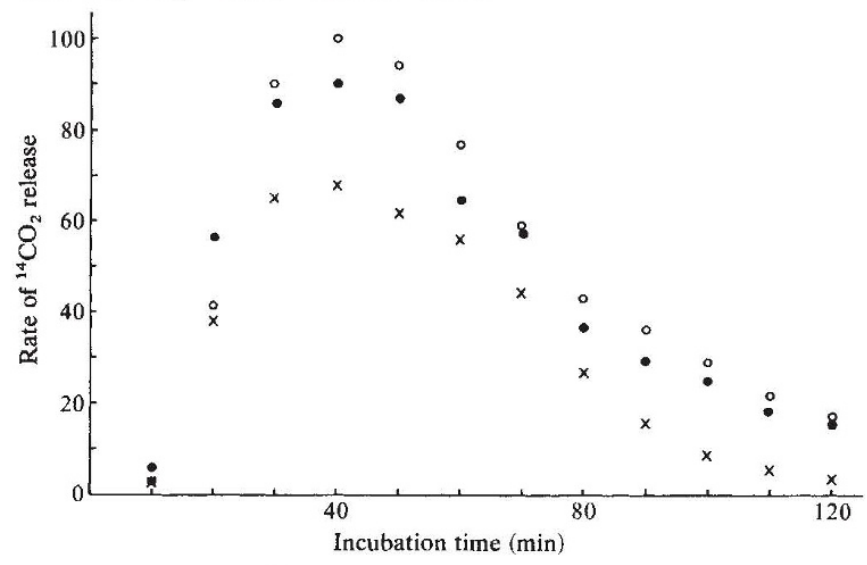

Fig. 1 Rate of ${ }^{14} \mathrm{CO}_{2}$ release from labelled tyrosine plotted against incubation time. The exponential increase in rate before $50 \mathrm{~min}$ of incubation is from isotopic equilibrium ${ }^{6}$. The rate of ${ }^{14} \mathrm{CO}_{2}$ release maintained steady-state values between 50 and 120 min of incubation. $\mathrm{GnRH}\left(5 \times 10^{-6} \mathrm{M}\right)$ added to the preparation $(\times)$ gave $\sim 30 \%$ inhibition of dopamine synthesis. Naloxone at $5 \times 10^{-6} \mathrm{M}$ together with GnRH blocked $70 \%$ of this inhibition (O). O, Control.
Met-enkephalin $\left(10^{-5} \mathrm{M}\right)$ added to the incubation mixture reduced ${ }^{14} \mathrm{CO}_{2}$ release by $\sim 40 \%$. Although some of this inhibition could be due to the degradation of the enkephalin releasing unlabelled tyrosine, we showed by kinetic studies using added unlabelled tyrosine that $>10 \%$ of this inhibition was a direct effect. Other opioid $\delta$-receptor drugs, for example, D-Ala ${ }^{2}$ Met-enkephalin and Metkephamid ${ }^{8}$ at $10^{-5} \mathrm{M}$ also inhibited dopamine synthesis by $\sim 10 \%$ and $20 \%$ respectively and this inhibition was not blocked by naloxone. In contrast, the $11 \%$ inhibition of dopamine synthesis by sufentany ${ }^{1}\left(10^{-5} \mathrm{M}\right)$, a $\mu$-receptor drug, was almost totally blocked by naloxone.

When $\mathrm{GnRH}\left(5 \times 10^{-6} \mathrm{M}\right)$ was incubated with the synaptosomal preparation, the ${ }^{14} \mathrm{CO}_{2}$ release was reduced to $73.4 \pm$ $6.6 \%$ of the normal rate. (The relative amounts of ${ }^{14} \mathrm{CO}_{2}$ released from the added tyrosine are shown in Fig. 1.) Naloxone $\left(5 \times 10^{-6} \mathrm{M}\right)$ together with $\mathrm{GnRH}\left(5 \times 10^{-6} \mathrm{M}\right)$ blocked $\sim 70 \%$ of the inhibitory effect. The normal ${ }^{14} \mathrm{CO}_{2}$ release was reduced by $\mathrm{GnRH}$ at $1 \times 10^{-6} \mathrm{M}$ and $5 \times 10^{-7} \mathrm{M}$ to $83.1 \pm 3.8 \%$ and $89.9 \pm 2.7 \%$ respectively. GnRH at a concentration of $<1 \times$ $10^{-8} \mathrm{M}$ had no significant effect.

These data show that $\mathrm{GnRH}$ and $\delta$ - and $\mu$-receptor opioids all have similar inhibitory effects on dopamine synthesis. We therefore postulate that GnRH exerts a negative feedback action on dopaminergic neurones, that is, GnRH inhibits it own release by inhibiting dopamine synthesis.

This work was partially supported by National Science Foundation R.O.C.

Received 14 October 1981; accepted 11 February 1982.

1. Meites, J., Bruni, J. F., Van Vugt, D. A. \& Smith, A. F. Life Sci. 24, 1325 (1979). 2. Rotsztejn, W. H., Drouva, S. V., Pattoa, E. \& Kordon, C. Nature 274, 281 (1978). 3. McNeill, T. H. \& Sladek, J. R. Science 200, 72 (1978).

4. Weiner, N. \& Rabadjija, M. J. Pharmac. exp. Ther. 160, 61 (1968).

5. Kuczenski, R. \& Segal, D. S. J. Neurochem. 22, 1039 (1974).

6. Wang, W. K. \& Chiang, Y. Bull. Inst. Zool. Acad. Sin. 10, 69 (1977).

7. Wang, W. K. \& Chiang, Y. A. Rep. Inst. Phys. Acad. Sin. 10, 69 (1980)

8. Frederickson, R. C. A., Smithwick, E. L., Shuman, R. \& Bemis, K. G. Science 211, 603 (1981).

\section{Glutamate regulates adenylate cyclase and guanylate cyclase activities in an isolated membrane preparation from insect muscle}

\section{Neil L. Robinson*, Paulette M. Cox \& Paul Greengard}

Department of Pharmacology, Yale University School of Medicine, New Haven, Connecticut 06510, USA

It is generally believed that glutamate serves as a neurotransmitter at many vertebrate and invertebrate synapses. There is, however, little information concerning the possible involvement of cyclic nucleotides as intracellular second messengers for any of the postsynaptic actions of glutamate. Direct activation of adenylate cyclase has been reported for several neurotransmitters and neuromodulators ${ }^{1}$, but no such effect has been reported for glutamate. Moreover, although several neurotransmitters including glutamate have been shown to increase cyclic GMP levels in intact preparations of nerve and muscle tissue ${ }^{2,3}$ apparently by promoting $\mathrm{Ca}^{2+}$ entry into the cells, no neurotransmitter has been shown to activate guanylate cyclase in a cell-free preparation. $\mathrm{L}$-Glutamate is the prime candidate for the neurotransmitter at the excitatory neuromuscular synapses in insects ${ }^{4}$. Moreover, recent studies have shown that glutamate application raises both cyclic $A M P^{5}$ and cyclic GMP levels (P.M.C., unpublished observations) in insect muscle. To determine the mechanism underlying these increases, we have studied the effect of glutamate in a membrane fraction prepared from this muscle, and report here that the neurotransmitter activates both adenylate cyclase and guanylate cyclase in the membrane preparation, and that the activation by glutamate of guanylate cyclase is calcium independent.

* Present address: Department of Zoology, University of Nottingham, Nottingham NG7 2RD, UK. 